\title{
PECULIARITIES OF FORMATION OF VALUE ORIENTATIONS OF MODERN STUDENT YOUTH
}

\author{
Dieniezhnikov S. S., Pshenychna L. V.
}

\section{INTRODUCTION}

One of the current trends in the development of science is the growing interest in the study of the substantive features of the individual consciousness of the individual as an integrated and multidimensional reflection of reality. The question of the need to study the individual specifics of inner life, the reconstruction of the subjective world-view of the individual is increasingly discussed. In a situation of breaking social stereotypes and new socio-cultural trends, which take effect, the formation of structures of individual consciousness becomes especially important.

Young people as a special social group are constantly in the focus of research of philosophers, psychologists, educators, sociologists, because it is a sensitive indicator of the changes taking place and determines the overall potential of society. The future state of society largely depends on the value foundation that will be formed in the younger generation. At the same time, the revaluation of values is inevitable in the conditions of breaking the established principles, their crisis is most manifested in the consciousness of this social group. Many researchers note that the generation of current students, known as the Next generation, has specific values characteristic of the postmodern era.

We know that the neoplasms of youth are closely linked with the ongoing social changes that determine the dynamics of the socialization process. According to a number of foreign and domestic researchers, the situation of social change requires the simultaneous manifestation of two opposite in their function of individual psychological characteristics - social lability, flexibility, ensuring constant adaptation to the changing social world, and developed social identity, which creates the inner "core", which serves as a starting point for the process of self-determination, both personal and social. The dynamics of the process of social construction of reality requires a person to constantly choose a social position, mode of action, means of achieving their goals, these very goals among the many existing ones. 


\section{Needs and interests as factors in the formation of value orientations of student youth}

A number of studies note that adolescence is sensitive, very favorable for the formation of value orientations as a stable personality trait that contributes to the formation of worldview. A distinctive feature of age is a sharp increase in self-reflection, i.e., the desire to self-knowledge of his personality, to assess its capabilities and abilities, the choice of their path in life.

According to Savotina N.A., questions about the meaning of life are most common and especially pressing in adolescence. The ability to set goals, find your place - an important indicator of personal maturity in adolescence. The creator of logotherapy considers the lack of a meaningful purpose in life to be one of the causes of the so-called noogenic neurosis, which is manifested primarily in boredom and apathy, in the inner emptiness. She notes that the phenomenon of existential vacuum, the lack of meaning in life in recent years is both increasing and spreading. The problem of finding the meaning of their existence, defining life goals is important for maintaining the mental and psychological health of any person and at any age. But there is a period in the life of everyone, when it becomes really key, determining - this is the period of student life ${ }^{1}$.

Psychologists argued that in youth produced value orientations (scientific-theoretical, philosophical, moral, aesthetic), which reveals the very essence of man; the worldview as a system of generalized ideas about the world as a whole, the surrounding reality, other people, oneself and readiness to be guided by it in activity develops; a conscious, generalized, final attitude to life is formed, which allows to reach the problem of the meaning of human life.

The category of "values" is one of the most difficult in pedagogy, philosophy, sociology and psychology. References analysis reveals ambiguity in the definition of the terms "values" and "value orientations".

From the point of view of Melnyk A.A., values are both motivational and cognitive formations. They direct, organize, orient human behavior to specific goals and at the same time determine the cognitive work with information. Values act for the individual as some criteria for assessing reality, in particular, other people, as well as himself. At the same time, values are the categories by which a person denotes certain phenomena of the world. Thus, values are the basis for human understanding and evaluation of social objects and situations, and therefore the basis for knowledge and construction of a holistic image of the social world. The

1 Савотина Н.А. Гражданские ценности в контексте проблем социализации студенческой молодёжи. Педагогика. 2010. № 7. С. 37-45. 
individual is aware of the world through the prism of values, i.e., values determine the process of human cognition of the social world ${ }^{2}$.

In addition, values act as the formation of the motivational sphere and regulate the social behavior of people. They represent some final (ideal) goals to which the individual aspires, gives the chance to make decisions in a situation of a choice, activate and direct behavior and activity of the person. In this guise, values are realized in value orientations and determine the element of the dispositional structure of the individual. Value orientations guide and correct the process of human goal-setting, determine the differences and the nature of the individual's relationship with the surrounding reality and thus to some extent determine the characteristics of its behavior. In other words, value orientations carry out mental regulation of social activity and behavior of the subject in the social environment.

Thus, values can be considered both as elements of the cognitive structure of the individual, and as elements of its motivational sphere. This "double" position is explained by their semantic nature. It is meaning that is the basis for cognition of the world and it sets the direction and activates human activity. Values, being semantic formations, "connect" the cognitive and motivational spheres, integrate them into a single semantic sphere, giving the individual a certain integrity.

Shpot O.V. speaks about the existence of a kind of "nodes" that combine different activities into integral personal structures, identifies them with the value formations that form the basis of personality ${ }^{3}$.

A number of authors independently proposed to distinguish between two classes of values: values-goals of life or terminal values, on the one hand, and values-principles of life or instrumental values, on the other hand.

According to Bondar O.O., the system of value orientations determines the life perspective, "vector" of personality development, being its most important source and mechanism, and becomes a psychological body that connects the individual and the social environment, performing both regulatory functions of behavior and determination of its purpose ${ }^{4}$.

2 Мельник А.А. Смисложиттєві та ціннісні орієнтації студентської молоді. Методологї̈ та технологї̈ практичної психології в системі вищої освіти: друга Міжнародна науково-практична конференція: тези доповідей / МОН України, НПУ ім. М.П. Драгоманова, Ін-т соціології, психології та управління, Каф. практичної психології та психотерапії; [редкол.: В.Б. Євтух, Н.І. Пов'якель, І.С. Булах та ін.]. Київ : НПУ ім. М.П. Драгоманова, 2009. С. 114-116.

Шпот О.В. Дослідження впливу релігійності на розвиток духовних цінностей сучасної молоді: дипл. робота. Суми: СумДПУ ім. А.С. Макаренка, 2015. 73 с.

4 Боднар О.О. Співвідношення типів цінностей особистості і соціальної мужності як цінності. Становлення иінностей у психологічному вимірі соціального буття особистості. Соціальна мужність як иінність: матеріали Міжнародної науково-практичної конференції, 3-4 червня 2010 р., Львів-Кам’янець-Подільський / МОН України, Львівський національний ун-т ім. І. Франка; Кам'янець-Подільський національний ун-т ім. І. Огієнка та ін.; [редкол.: С.Д. Максименко, В.Й. Бочелюк, В.О. Васютинський та ін.]. Кам'янець-Подільський: Аксіома, 2010. С. 40-42. 
According to Voloshina S.V., "value internally illuminates a person's whole life, filling it with simplicity and true freedom". She notes in this regard that values acquire the quality of real motives and sources of meaningfulness of life, leading to the growth and improvement of personality in the process of their own consistent development, i.e., value orientations, as a psychological organ, mechanism of personal growth and self-development, and represent a dynamic system ${ }^{5}$.

Thus, personal values are genetically derived from the values of social groups and communities of different scales. Selection, appropriation and assimilation of social values by an individual are mediated by his social identity and values of reference small contact groups, which can be both a catalyst and a barrier to the assimilation of values of large social groups, including universal values. Personal values act as internal carriers of social regulation, rooted in the structure of personality.

We suggested that socio-economic transformations and fundamental reforms of modern Ukrainian society, which are an objective component of the social situation of personal development, will be reflected in changes in the structure of the value sphere of youth, most sensitive to social changes in society.

However, the solution of development problems that correspond to the logic of the formation of age-related psychological tumors, in our opinion, determines the features of the structure of values in student age. At the same time, there are structural and dynamic features of the hierarchy of value orientations at this age, corresponding to the development of personal autonomy.

Schwartz's questionnaire of values is widely used by researchers, which is aimed at studying the global, universal values that exist in every culture in one form or another. It is actively used in recent years in various countries. In general, the values in this concept are considered as some criteria for choosing and evaluating a person's actions, other people and events. They act as criteria by which a person builds his attitude to the world, including attitude to himself (self-attitude).

In this case, all values in the form of conscious goals are aimed at meeting three universal human needs:

1) the needs of individuals as biological organisms;

2) the needs of coordinated social interaction;

3) needs related to the survival and well-being of social groups ${ }^{6}$.

5 Волошина С.В. Розвиток національних і загальнолюдських цінностей домінувальний фактор самореалізації особистості: (модель освітнього соціалізувального простору). Виховна робота в школі. 2015. № 11. С. 6-8.

${ }^{6}$ Семків I. Крос-культурний аспект дослідження цінностей. Методологї та технології практичної психології в системі вищої освіти: друга Міжнародна науково-практична конференція: тези доповідей / $\mathrm{MOH}$ України, НПУ ім. М.П. Драгоманова, Ін-т соціології, психології та управління, Каф. практичної психології та психотерапії; [редкол.: В.Б. Євтух, Н І. Пов'якель, І.С. Булах та ін.]. Київ : НПУ ім. М.П. Драгоманова, 2009. С. 174-176. 
All these needs are met to one degree or another in the implementation of ten different motivational types, which are formed by certain personality values. They determine the direction of specific actions of the individual and more broadly all his life. Thus, based on extensive scientific material, Oleksin I.Ya. derives from the three universal human needs the main motivational types. In turn, each motivational type corresponds to a certain motivational goal:

- Self-regulation (independence). Motivational goal - independent thought and action (choice, creativity, research), which are dictated by the individual's need to be autonomous and independent.

- Stimulation (fullness of life sensations). Motivational goal - novelty and competition in life, necessary to maintain the optimal level of activity of the body.

- Hedonism. Motivational goal - pleasure, sensual pleasure, enthusiasm for life. This motivational type is derived from the need to meet biological needs and is tested at the same time satisfaction, which is emphasized by scientists in various fields of knowledge.

- Achievement. Motivational goal - to achieve personal success through the exercise of competence based on recognized cultural standards, thereby obtaining social approval. The necessity to meet the need for personal success is emphasized in many works.

- Power. Motivational goal - the acquisition of social status, prestige and domination over people. This motivational type differs from the previous one in that it refers to the achievement of domination within the general social system, rather than in a specific interaction. Such a need for domination and power was considered by analysts of social motives and values.

- Security. Motivational goal - stability, security and harmony of society, family and the individual. It follows from the basic individual and group needs.

- Conformism. Motivational goal - limiting actions and motives that harm others or violate social expectations and norms; is derived from the needs of groups for self-survival and the need for the individual to interact with other people, while suppressing their socially destructive tendencies. The values of conformism emphasize the self-limitation of the individual in his daily interaction with other individuals.

- Tradition. Motivational goal - respect and observance of customs, acceptance and recognition of ideas that exist in a particular culture and religion. Traditional behavior becomes a symbol of group solidarity, an expression of the uniqueness of its world and presumed guarantors of survival. 
- Commitment (kindness). Motivational goal - to support and improve the well-being of people with whom a person is in constant contact and maintains personal relationships. It is determined by the need for positive interaction in order to contribute to the well-being of the group, as well as the biological needs of the affiliate.

- Universalism. Motivational goal - understanding, gratitude, tolerance and support for the well-being of all people and nature. This motivational type was not derived a priori from these three universal human needs, but was identified empirically in the study of values. We can say that the realization of the motivational goal of this block provides an opportunity to meet all universal needs ${ }^{7}$.

At the level of normative ideals, beliefs and behavior, the most important value for students is independence, which determines the desire to think freely and act in creativity and research. Independence as a value is derived from the organic need for self-control and self-government, as well as from the interactive needs for autonomy and independence.

In second place at the level of normative ideals for students was such an indicator as safety. Motivational goal of this type - security for other people and yourself, harmony, stability of society and relationships, social order, family security, national security, mutual location, mutual assistance, cleanliness, sense of belonging, health.

An interesting fact emerges regarding the value of "stimulation", which took second place among individual priorities and the penultimate, 9th place, among the values at the level of normative ideals. In this case, the contradiction of students at the level of ideals and behavior is clearly visible. Stimulation is derived from the need for diversity and deep experiences, is the pursuit of novelty to maintain optimal levels of activity. Biologically determined variations in the need for stimulation, mediated by social experience, lead to individual differences in the importance of this value.

In third place among the values at the level of normative ideals and individual priorities - commitment (in some versions it is called kindness). This is a more "prosocial" type of values compared to universalism. The benevolence that underlies it is focused on well-being in daily interaction with loved ones. This type of values is considered to be derived from the need for positive interaction, affiliation and ensuring the prosperity of the group. Its motivational goal is to preserve the well-being of people with whom the individual is in personal contact (usefulness, loyalty, indulgence, honesty, responsibility, friendship, mature love).

${ }^{7}$ Олексин І.Я. Аксіологічний вимір життєвого світу особистості. Практична філософія. 2017. № 2. С. 38-44. 
In the last place among the values at the level of normative ideals and individual priorities of students - traditions. As you know, any social group produces its own symbols and rituals. Their role and functioning are determined by the experience of the group and are enshrined in traditions and customs. The traditional way of behaving becomes a symbol of group solidarity, an expression of common values and a guarantee of survival. Traditions often take the form of rites, beliefs and norms of behavior. The motivational goal of this value is respect, acceptance of customs and ideas that exist in the culture (respect for traditions, humility, piety, acceptance of one's destiny, moderation), and their observance.

Among the values least important to young people was power. Students ranked it 8th in normative ideals and 9th in individual priorities. The central goal of this type of values is to achieve social status or prestige, control or domination over people and means (authority, wealth, social power, preservation of their social image, public recognition). The value of power focuses on social respect, emphasizes the achievement or maintenance of a dominant position within the entire social system.

Unpopular value among young people is conformism (8th place among values at the level of individual priorities). The defining motivational goal of this type is to restrain and prevent actions, as well as inclinations and motivations to actions that may harm others or do not meet social expectations. This value is derived from the requirement to restrain tendencies that have negative social consequences.

As can be seen from the study, the age characteristics of the value sphere in adolescence are associated with the solution of the most important task of development - overcoming dependence and the formation of personal autonomy. The growing importance of the value of self-regulation, motivation for change and self-development is a characteristic trend in the development of the value sphere in adolescence. Another trend is the intensification of value contradictions, in which the individualistic focus on personal achievement contradicts the collectivist concern for social welfare. The solution of this contradiction is associated with the development of forms of cooperation and cooperation of man with other people in significant activities.

Analysis of students' values shows that some values are in relation to each other in a dynamic relationship as opposed. For example, independence, stimulation - on one pole among the values that are most often manifested in the social behavior of the individual, and traditions, power, conformism - on the other. Independence and stimulation are contrary to conformism, tradition and security, as there is some opposition between preserving one's own independent views and actions and preserving traditions, protecting the stability and immutability of society. Universal values and commitment are contrary to power and achievement, as the 
acceptance of other people as equals and a friendly attitude to their wellbeing are poorly combined with the pursuit of their own goals and dominance. As can be seen, among the values manifested at the level of behavior of young people, hedonism contradicts conformism and tradition, expressing the conflict between indulging oneself and restraining one's own needs and accepting social restrictions. At the level of ideals, we do not observe this contradiction in students ${ }^{8}$.

We found that the following pairs have consistent relationships among students' value orientations:

- achievements and hedonism - associated with pleasure, indulgence in oneself (both relate to indulgence of one's desires);

- hedonism and stimulation - combined with the desire for affective and pleasant arousal (cause the desire for positive emotional experience);

- stimulation (fullness of life sensations) and independence include intrinsic motivation for creativity and the desire to change personality.

Thus, the structure of value orientations of modern students is characterized by a strong focus on achievement and personal success while reducing the importance of commitment (concern for the well-being of others and society). The change in the structure of values reflects the shift of social priorities in favor of their own well-being and individualism against social interest and collectivism. This differs from the model of universal value structure proposed by Schwartz.

Thus, studies conducted in 53 countries, including Ukraine, revealed the phenomenon of consensus of values, which confirms the pan-cultural universal nature of the development of value orientations in different nations. According to the results of the work of S. Schwartz, the hierarchy of values is as follows: commitment; independence (self-regulation); universalism; achievement; security; conformism; hedonism; stimulation; traditions; power. In this list in the first place - commitment, and not as in our study - independence.

In addition, we compared our results with the results of studies by other authors conducted in recent years. Thus, in the work of Yu.I. Tereshchenko there is a strong tendency to preserve such basic values of Ukrainian culture as collectivism and femininity, along with the emergence and development of the younger generations of Ukrainians values of individualism and masculinity (ambition, motivation to achieve) ${ }^{9}$.

${ }^{8}$ Попович М.В. Аксіологічні уявлення в груповій свідомості студентів вищих духовних навчальних закладів. Практична філософія. 2016. № 2. С. 23-28.

9 Терещенко Ю.І. Педагогіка: філософія затвердження людського в людині. Практична філософія. 2009. № 4. С. 110-119. 
Isakova O.I. in her work emphasizes the importance of collectivism, justice, focus on a better future, aiming at a quick solution to vital problems. A review of research on the values of Ukrainians and their transformation in the last decade shows that along with the preserved basic values of Ukrainian culture in the minds of Ukrainians there is a change of values on the axis "individualism - collectivism" towards greater individualism" ${ }^{10}$.

The study of the influence of modern socio-economic conditions in our country on the change of value orientations of people in different social groups shows the formation of a new type of personality orientation, characterized by individualized orientation to personal, including economic values such as material security, entrepreneurship, property and wealth. So, in our study it was found that the value orientations of students are characterized primarily by increased self-focus, self-reliance (volitional qualities, rationality in behavior, the desire to act independently and decisively) and reduced role and importance of personality traits, especially important in contact with others people (sensitivity, respect for the person, ability to listen and understand another, etc.).

We have shown that individualistic values that serve personal growth and development are more important for students. It is difficult to say whether the identified differences in value priorities are the result of an internal transformation of cultural values or the result of the influence of age differences. But the results of the work show that in a number of values of students there is the emergence of specific features that affect the basic principles of the Ukrainian national character. Young Ukrainians reject the values of collectivism: respect for traditions, moderation, equality. This means that for students of the Next generation, significant motives for behavior are: the desire to achieve personal success, choice of their own goals, independence, well-being and attitude to social inequality.

In general, it is reminiscent of the process of acculturation of ethnic minorities in a dominant society, when groups are advised to part with those cultural traits that are valuable but not adaptive.

\section{Value orientations of modern students in the conditions of dynamic development of society}

The study of the modernization potential of Ukrainian society and various social groups is of key importance in the new modern socioeconomic conditions. Undoubtedly, there is a certain modernization potential

\footnotetext{
${ }^{10}$ Ісакова О.І. Аксіологія здоров'я молоді у сучасній філософській антропології. Загальна теорія здоров'я $i$ здоров'язбереження: колективна монографія / $\mathrm{MOH}$ України, Харківський національний педагогічний ун-т ім. Г.С. Сковороди; за заг. ред. Ю.Д. Бойчука. Харків : Рожко С.Г., 2017. С. 40-45.
} 
in Ukrainian society. Thus, the data of national sociological centers record the presence of value orientations and qualitative characteristics of human capital required for the implementation of the modernization project.

At the same time, almost all researchers of modernization agree with the fact that in today's modernization orientations and values are not a significant regulator of everyday practices: Ukrainians generally positively assess personal initiative, individuality, independence, but give negative assessments of the value characteristics of Ukrainian reality, especially express uncertainty in the demand for "innovative" qualities to achieve success in life.

To intensify the behavioral strategies of the population, which are correlated with the Ukrainian modernization project, is the primary task of the state.

Currently, the study of socio-cultural foundations of modernization in Ukraine is becoming especially relevant. Within this area, it is necessary to identify the amounts of human resources that have the potential for modernization, to identify groups - "carriers" of modernization change. Based on this, we can talk about modernization orientations and values, the modernization potential of the population.

In general, modernization orientations and values can be considered in a broad sense as values and social attitudes of the population in various spheres of life: socio-economic, political, spiritual and moral - in the context of the movement towards a society of "modernity". They form the foundation of modernization potential.

Modern Ukrainian researchers identify different types of potential. According to Semkiv I., social potential is "an integral concept that characterizes the capabilities of the state, firms <...> individuals, groups, populations, various spheres of life and society as a whole in solving promising problems of social development"11. Burukovska $\mathrm{N}$. defines the social potential of modernization as a set of socio-economic resources of different segments and groups of the population that can be implemented during the modernization project ${ }^{12}$. Under the innovative potential of the

${ }^{11}$ Семків I. Крос-культурний аспект дослідження цінностей. Методології ma технології практичної психології в системі вищої освіти: друга Міжнародна науково-практична конференція: тези доповідей / МОН України, НПУ ім. М.П. Драгоманова, Ін-т соціології, психології та управління, Каф. практичної психології та психотерапії; [редкол.: В.Б. Євтух, Н.І. Пов'якель, І. С. Булах та ін.]. Київ : НПУ ім. М. П. Драгоманова, 2009. С. 174-176.

12 Буруковська Н. Міф як засіб формування нових ціннісних орієнтацій в сфері сучасних наукових досліджень. Гуманітарно-наукове знання: розмаїття парадигми: матеріали міжнародної наукової конференції, 14-15 жовтня 2013 р., м. Чернівці / МОН України, Чернівецький національний ун-т ім. Ю. Федьковича; [редкол.: М.Г. Марчук, О.В. Рупташ, С.І. Мудра та ін.]. Чернівці : Чернівецький національний ун-т, 2013. С. 183-184. 
country Kuznetsov M.A. understands opportunities for development, implementation and dissemination of innovations (including new ideas, technologies, management methods, socio-cultural patterns, etc. $)^{13}$. Tereshchenko Yu.I. determines the level of social innovation potential through "the ability and readiness of society to radically transform its own system, its fundamental institutions and, accordingly, the social structure" ${ }^{14}$.

Summarizing different points of view, we can conclude that the modernization potential is a set of socio-economic, cultural, moral, ideological and political resources (abilities, capabilities and readiness) of layers and groups of Ukrainian society that can be implemented during the modernization project. These resources are divided into different areas: political, economic, cultural, spiritual and moral, which are closely interrelated.

Thus, in the political sphere, the formation of modernization potential is evidenced by involvement in political processes, readiness to participate in the political life of the country (elections, meetings), positive perception of government, trust in state institutions, readiness for self-organization. In the economic sphere, an important criterion is the formation of the potential of entrepreneurial activity of the population (individual responsibility, independence, active life position, propensity to compete and risk, etc.), the absence of paternalistic expectations of the state. Within the cultural, spiritual and moral spheres it is necessary to search for unity in diversity, recognition of cultural diversity, formation of a positive identity, moral and ethical value system of the population, tolerance ${ }^{15}$.

Particular importance in the implementation of modernization, building an innovative economy is given to human resources and human capital. The quality of human potential (as a set of resources available to a person, inextricably linked to his personality) is important for assessing the prospects for modernization of Ukrainian society. It should be noted that recently there has been a tendency to consider the concept of "human potential' as more complete, and comprehensive than "human capital" as an integral concept.

13 Кузнєцов М.А. Структура почуття цінності власного життя у студентів. Особистість у кризових умовах та критичних ситуаціях життя: матеріали V Міжнародної науково-практичної конференції 28 лютого - 1 березня 2019 р. / МОН України, Сумський державний педагогічний ун-т ім. А.С. Макаренка; Ін-т психології ім. Г.С. Костюка НАПН України та ін.; [редкол.: С.Б. Кузікова, Р. Абрамцьов, А.В. Вертель та ін.]. Суми : Вид-во СумДПУ ім. А.С. Макаренка, 2019. C. 191-195.

14 Терещенко Ю.І. Педагогіка: філософія затвердження людського в людині. Практична філософія. 2009. № 4. С. 110-119.

15 Гавриленко М.О. Соціальні цінності та активність студента як провідні критерії та показники соціального виховання молоді. Соціальна педагогіка: теорія та практика. 2012. № 1. С. 43-48. 
The most valuable qualities of human capital in terms of socio-cultural modernization are, in our opinion, independence in action, independence in views, rationality, initiative and responsibility. The development of these qualities in young people should become a priority strategic task of modern government.

In the current conditions of Ukrainian society, technological and economic modernization has become a priority. However, such modernization is impossible without social actors who have modernization orientations and values, an innovative type of thinking. Ukraine's place in the globalizing world is related to the quality of its human potential, the ability of the population at the micro level to support modernization initiatives.

Modern Ukrainian youth enters life in rather difficult conditions of economic and social development of society. Problems of formation of the democratic, legal state put in the first place a task of formation of the personality of the young person as the subject of conscious activity.

Educating (upbringing) a citizen is an important task for all countries. It is especially relevant for Ukraine, which is in a transitional stage of historical development. The legacy of the past, crisis changes in all spheres of life determine the specifics of civic education in our country. Today, the position of a citizen of Ukraine, his relations with the state and society are changing radically. On the one hand, he had great opportunities to realize himself as an independent person, on the other - increased his responsibility for his own destiny and the fate of others. However, the centuries-old culture of Ukraine has developed in such a way that the omnipotence of the state, its interference in private life and control over the life of the public have led to the fact that even today Ukrainians, in fact, continue to feel "cog', believing that nothing depends on him ${ }^{16}$.

Researchers who are skeptical of modernization prospects in Ukraine often point to a lack of adequate human resources. The future of any society depends on whether the younger generation learns to live responsibly and to serve society. Among the components of assessing the quality of knowledge of graduates of higher education institutions is their civic competence. Integration into society is an important prerequisite for young people to become independent citizens and be able to take responsibility for maintaining a democratic legal order and the foundations of the state.

One of the most important factors that ensure the activity of young people in the implementation of reforms, the formation of economically strong, politically stable Ukraine, is the socio-psychological mood, willingness to act in accordance with certain social attitudes and values.

16 Кофанова Е. Гражданские ценности как фактор образования: о задачах гражданского образования. Новые знания. 2006. № 2. С. 11-13. 
Values and value consciousness can be both an accelerator of the transformations and its brake, so the task of studying the value content of youth activity becomes very significant and relevant. The problem of values has a multifaceted and multilevel nature.

Research conducted in the regions of our state indicates significant changes in the orientations and values of the younger generation. Many of them are replaced by "new" ones, some of the traditional ones move to the periphery of value consciousness, although they still play a significant role in the motivational and value structure of a certain part of the youth. Its attitudes and behavior - only to a greater or lesser extent an adequate response to changes in society and based on their own ideas about the importance of certain values, their role in self-realization, as well as due to the weak influence of Ukrainian society on the formation of healthy needs and the rooting of high spiritual values in consciousness and behavior ${ }^{17}$.

Based on the generalization of information from modern research, we can build a hierarchy of life values, which has the following form:

1) health;

2) love;

3) good friends;

4) a happy family;

5) materially secure life;

6) life wisdom;

7) self-confidence;

8) interesting work;

9) public recognition;

10) the possibility of intellectual growth;

11) freedom of judgment;

12) pleasure, entertainment;

13) prosperous socio-economic situation in Ukraine;

14) equality in society;

15) creativity and self-realization;

17) contemplation of the beauty of nature and works of $\operatorname{art}^{18}$.

17 Кобильник Л.Б. Особливості ціннісних орієнтацій студентів різного фаху. Методологї та технологї практичної психологї̈ в системі вищої освіти: друга Міжнародна науково-практична конференція: тези доповідей / МОН України, НПУ ім. М.П. Драгоманова, Ін-т соціології, психології та управління, Каф. практичної психології та психотерапії; [редкол.: В.Б. Євтух, Н.І. Пов'якель, І.С. Булах та ін.]. Київ : НПУ ім. М.П. Драгоманова, 2009. С. 86-88.

${ }_{18}$ Кишакевич Ю.Л. Ієрархія цінностей у вихованні студентської молоді. Нові технологї навчання : Наук.-метод. зб.: Вип. 31. Київ : Наук.-метод. центр вищ. освіти, 2018. С. 81-86. 
It should be noted that, despite the youth, students took the selection of values seriously - "health", "love", "good friends", "happy family" received high positions, and "pleasure and entertainment" were placed on the 12th place. However, they underestimate the social importance of the socioeconomic situation in Ukraine (13th place), do not attach importance to social stratification and inequality in society (14th place), which has become one of the main problems in modern Ukraine.

"Public recognition" (9th place) in the hierarchy follows the "interesting work" (8th place). This indicates the desire of students that their work in the future should be appreciated by society and the state. Many students associate their idea of a successful career with a high social status in society and a decent salary. Young people prefer "materially secure life" (5th place) to "creativity and self-realization' (15th place).

So, it is not surprising that the students put "self-confidence" in 7th place. Young people, being in the process of forming social status, in search of their place in life, need support from parents and society as a whole. Confidence in the correctness of the chosen path, profession, employment after graduation, a decent salary - the most important motives for learning and self-improvement for young people.

Boys and girls generally ranked values almost unanimously. The exceptions were "love", which was valued mainly by girls, and "good friends", which turned out to be more important for young men.

In the conditions of social transformations in the minds of young people there are complex processes of reassessment of values, their own ideas are formed about what is important for further life advancement. The ideals of pragmatism and utilitarianism were replaced by selfless work for the benefit of society and the state. Yet confidence in the future inspires the priority of family values, love and friendship in student responses.

Modern student youth in general has a positive potential social appearance. The motivation of their social behavior is based primarily on the principles of morality - respect for parents, the older generation, the history of their country. These are the principles that are an important prerequisite for social and political stability in society.

Student youth is one of the strategic resources of social development, the inclusion of which in economic, political and social processes can provide additional impetus to the development of both the region and the country as a whole.

Young people as a special socio-demographic group differs in that the most pressing issues are their place in the world around them and, accordingly, the meaning and destiny of the world itself, including their own country and place of residence. Creating conditions for maximum use of the constructive component of the civic potential of the young generation is 
especially important in the conditions of open relations, high dynamics of change and competition, which is intensifying in the modern world, as well as incomplete period of institutional reforms in Ukraine ${ }^{19}$.

One of the conditions for the formation of value orientations in student youth can be the study of social and humanitarian disciplines in higher education institutions in order to acquire skills of self-organization, mastering ways to effectively solve problems. The ability to formulate their interests, legitimately formalize them, choose and delegate their representatives to represent these interests, look for allies and partners, mastering the art of finding compromises with the authorities become one of the basic in building social relations. In modern society, a person must be able to defend their interests in public, organize public examinations and participate in them, have the skills to behave in a competitive business environment, freely navigate the main issues of modern politics ${ }^{20}$.

Effective and transparent program activities in the field of youth policy can be formed and implemented through the interaction of three main actors of social partnership - civil society institutions, government and business. Work in the youth environment is able to be carried out only if the youth themselves participate in these processes, taking into account their interests and strategic perspectives. Such participation should not be reduced to a passive reaction to efforts to involve young people in the processes of "adult life". This can happen only on the basis of reliable, objective, constantly updated information about the current situation of student youth as a special socio-age group, their views, social well-being, needs ${ }^{21}$.

The attitude to youth has always been relevant for the state and society. It absorbed the development by new generations of the achieved level of development of society and the state and was expressed in the fact that, first, how young people perceive the life of this society and the functioning of this state; secondly, how the young generation evaluates its contribution to the social development and activities of the state, and, in this connection, what was the reaction of previous generations to the youth; thirdly, to what extent young people become a factor of development or a factor that hinders the development of society and the state.

Youth policy in the previous stages did not always meet the needs of youth development as a new social force. In this regard, science and practice

19 Гавриленко М.О. Соціальні цінності та активність студента як провідні критерії та показники соціального виховання молоді. Соціальна педагогіка: теорія та практика. 2012. № 1. С. 43-48.

${ }_{20}^{20}$ Калошин В.Ф. Загальнолюдські цінності в освіті. Управління школою. 2019. № 4/6. С. 41-49.

${ }^{21}$ Олексин І.Я. Аксіологічний вимір життєвого світу особистості. Практична філософія. 2017. № 2. С. 38-44. 
are faced with the need to comprehend the new situation in which young people today. As a result of this understanding, a new view of many problems must be developed in society, including the place and role of the younger generation in the life of our society, a view that more fully meets the requirements of the new historical situation.

The state must to create optimal conditions for the involvement of young men and women in all spheres of social life, to develop creativity and amateurism of young people, to form confidence in their own prospects, to protect the social interests of young people in the transition to market relations.

The implementation of this goal involves the selection of the following priorities:

- Formation of patriotism in youth, moral and spiritual development of youth.

- Ensuring the social rights of young people in the field of labor, education and health care.

- Creating conditions for self-realization of socio-economic needs of youth.

- Creating conditions for intellectual and physical development of youth.

- Support and stimulation of a positive public youth initiative.

- Involvement of youth in international cultural, economic, scientific and educational processes ${ }^{22}$.

The spiritual and physical health of young people is the strategic capital of the country and an important factor in its modern development. The formation of moral and spiritual values of adolescents and young people should be based on the study and promotion of world and national cultural values and should be based on age. Characteristics of values inherent in young people, reflects the diversity of living conditions and destinies of young people, a wide range of values. It should be borne in mind that the formation of aesthetic and moral values of young people is significantly influenced by the media, especially electronic. The propaganda of the cult of cruelty and violence puts massive pressure on the psychological state of young people, forms appropriate patterns of behavior and stereotypes of life. Restrictions on the promotion of the cult of power, the efforts of the media, the progressive intelligent, the orientation of the educational process as a whole should contribute to the creation of a favorable environment in society, in which such personal qualities as decency, dignity, patriotism,

22 Горлинський В.В. Інституційний вимір безпечного і сталого розвитку в умовах мережного суспільства. Практична філософія. 2012. № 4. С. 107-112. 
professionalism, respect for elders, awareness of responsibility for themselves and loved ones will be prestigious ${ }^{23}$.

In general, we can note the following trends, characteristic of the value priorities of modern youth:

- the importance of spiritual and moral values among young people has significantly decreased;

- in the context of socio-economic transformation of society, education does not lose its value, although the attitude of young people to education is increasingly expressed in the status and material interest;

- is concerned about a number of complex psychological shifts in the minds of young people due to growing nihilism and infantilism in the youth environment;

- the study of progressive customs and traditions is of great importance for the revival of the moral culture of the individual and has a positive effect on human relationships.

The most important institution that forms a system of values in a social crisis and growing social disorganization is the institution of education. Being a social value, the institute of education is able to form a young person's moral and ethical immunity, preserve the basic system of values and, above all, the subsystem of socio-cultural values that are subject to maximum deformation.

The recovery of society is directly related to the recovery of education, both secondary and higher. It is necessary to assess the threat posed by the existing system of selective education, when quality education is available only to children of parents who have the financial resources or authority. Otherwise, society will return to a social class capable of rejecting the country decades ago, making it an outcast in the international community.

Social transformation in Ukraine, accompanied by the processes of globalization, has led to a situation where the search for a new socio-cultural identity becomes the main task primarily for young people. However, young people will never be able to solve this problem on their own. Therefore, the need for broad social support for young people and an effective state youth policy is obvious. The basis of this process should be a new social consensus - the consensus of parents and children. An important element of the state youth policy should be measures that can ensure the social integration of young people who have lost clarity and certainty in moral guidelines. It is also necessary to stop the decline of the prestige of

23 Балагура О. Глобалізація морально-духовних цінностей в освітньому просторі. Вища школа. 2013. № 8. С. 89-94. 
spirituality, because it carries the danger of spiritual degradation, which leads to the destruction of the individual and society as a whole ${ }^{24}$.

The formation of a harmoniously developed personality is the main task of education at all times. Harmoniously developed personality is inextricably linked with the idea of a just social order and moral attitude towards other people. Creating conditions for maximum self-realization of personal capabilities - the goal and means of successful socialization and humanization of social relations.

A large amount of scientific work aimed at studying the problem of values, both in philosophy and pedagogy, and in psychology and sociology, suggests that, on the one hand, this problem is well studied by domestic and foreign authors. On the other hand, the problem of values will always be relevant due to the fact that values, performing an important function, both in the life of a community of people and in the life of an individual, are dynamic. Stability and dynamics of values depend on what values in a given historical epoch are a priority in society and how they affect an individual, as well as on what values are relevant to the individual as a representative of this era.

Life values in the understanding of students are now represented in their minds in the form of values related to personal life, with the values of "Love, friendship, friends", "Ethical values". However, the whole range of values that can be represented in the value field of the individual is expressed in a small way. For students, the values of the "inner world of the individual", the values of "achievement of the individual" were not significant, which leads to the limitation of the activity of the individual and his creative abilities.

Peculiarities of the existence of the inner value world of students' personality can be presented as an integrated system in the form of a field of values, the content of which are such spheres of human life as spheres of life and relations, material and spiritual, understanding, goals and achievements, with "external the focus and the inner world".

The values of life in the understanding of students reflect what is for them "the main, important, significant, what can be valued, what is necessary or beneficial, what can be a goal or an ideal". Priority for the value world of students' personalities are the values of "personal life" in the field of life, relationship values and ethical values, which are the most significant and correspond to some major new developments of student age, such as life, family life, building values and ethical consciousness as guidelines for their own behavior.

The reflection of needs and interests in the value field of students' personality is expressed in the fact that the graduation course, both for

${ }^{24}$ Кострюков С. Загальнолюдські та національні культурні цінності: проблема єдності. Вища освіта Украӥни. 2008. № 3. С. 75-83. 
women and men is characterized by increasing importance of values related to the values of "work", as well as the fact that the greatest identity men and women, necessary for a high degree of mutual understanding, is observed at the age of 21-22 years, in the period of urgency of creating your own family. The volume of the perceived value field of female students is higher than the volume of the value field of male students (87\% of concepts for each woman and $13 \%$ of concepts for each man $)^{25}$.

Life values have a complex structure, which is determined by the focus on material or spiritual values, which is the basis for the selection of two types of personality, called conditionally "material" and "spiritual".

For the "material type of personality" is characterized by high general internality, internality in the field of failures, achievements, interpersonal and family relationships. These individuals can be described as active, energetic, enterprising, sane, realistic, practical, use experience, seek to take a worthy place in a particular social structure. These are individuals socially mature, balanced, calm, firm, in solving practical problems, avoid everything unusual, reliable in practical matters, tend to focus on group norms, trust the mind more than feelings, act on logic, replace intuition with calculation, do not strive for of what would be oneself.

For the "spiritual type of personality" is characterized by intuitive and humane perception of the world and people, the desire to be yourself and have value in their eyes, high sensitivity, deep reactions in the field of subtle emotions, gentleness to themselves and others, sentimentality and emotionality, activities aimed at achieving the goal, artistic perception of the world, the identity of the worldview and its own unique manner of behavior, refined taste and rich imagination, actions on intuition, not logic and common sense, interest in abstract problems ${ }^{26}$.

The value field of students is stable. The increase in the field of vital values of the individual occurs as a result of psychological and pedagogical influence on the individual in order to develop it. At the age of 18-19 years (2nd year) the value field of students is most subject to change as a result of psychological and pedagogical influence on the individual, which indicates the sensitivity of this age in the formation of the value field of the individual.

Working with students to expand their value field leads us to the conclusion that our analysis allows us to expand the value field of students on the parameters for which the program was formed, exactly, a higher

${ }^{25}$ Артьомова Т. Європейські цінності: інтелектуальний простір цивілізаційного діалогу. Економічна теорія. 2018. № 3. С. 5-28.

26 Лазарєв М.О. Самореалізація творчих і духовних цінностей особистості в евристичній освіті. Педагогічні науки: теорія, історія, інноваційні технологї: науковий журнал / МОН України, Сумський держ. пед. ун-т ім. А.С. Макаренка; [ред. кол.: А.А. Сбруєва, О.С. Антонова, Дж. Бішоп та ін.]. Суми : СумДПУ ім. А.С. Макаренка, 2014. № 7 (41). С. 270-280. 
representation in the value field of students such values as "ethical values", "inner world of the individual", "achievement of the individual".

However, the peculiarity of the value field of students' personality is the lack of clarity of the form in which values are reflected in the mind: in the form of value ideas or value orientations. To address this issue, priority areas of youth policy are developed, which outlines the objectives of the study of the value field of the student's personality in order to identify the form of existence of values in the form of values images, values orientation or personal values. The main task we see is that the expansion of the value field of students' personality was at the level of personal values, which, being realized, are crucial in the actualization of potential motives.

\section{CONCLUSIONS}

The model of formation of life and professional value orientations of modern students includes the following components: goals (social, psychological, didactic, educational); functions (educational, developmental, upbringing); content of activities in stages; forms (organization of educational process, research process, extracurricular activities); methods (diagnostics, formation of personality qualities, organization of activity, control and self-control); means (respectively by links); criteria for the formation of value orientations (cognitive, emotional, activity).

Arguing that value orientations perform a structural and creative function in relation to individual values, we studied the attitude of young people to the main components of their professional activity: communicative, diagnostic, prognostic, constructive, research, organizational and methodological, social.

Value orientations are not an independent indicator of the qualitative characteristics of personality, they can be considered only in connection with other substructures, but this component of personality is the connecting link, dialectically combines worldview and functional levels of personality into one dynamic system.

Value orientations have an objective-subjective basis. Reassessment of values in society can lead to a revision of the individual's value orientations. Value orientations - moral, cultural, professional core of personality. The degree of formation of value orientations can be judged on the level of formation of personality, its maturity, social position.

The most effective conditions for the formation of life and professional values are the implementation of special courses and special seminars on the problems of professional development of the student's personality, research work of students, joint activities of teachers and students, holding scientific and practical conferences, organizing research work in higher education institution, extracurricular activities in higher education institution, etc.

The technology of formation of life and professional value orientations of students is based on expansion and deepening of contacts and interaction 
of subjects of education and training with student's youth; using practiceoriented forms and methods (role-playing games, staging, brainstorming, project implementation, etc.) in order for students to gain experience in socio-cultural and professional connections and relationships focused on achieving success in their future professional activities.

The possibility of using factor analysis for the diagnosis of values as a basis for creating a typology of life and professional value orientations of student youth is substantiated. Diagnosis of general attitudes and expectations of students is the basis for choosing the appropriate socialization strategy.

In extracurricular activities, the formation of life and professional values of students is most effective in an environment of ease, freedom, emotional uplift, which requires: variability of content, forms (special courses, competitions, Olympiads, folk festivals, role-playing games, etc.), methods (diagnostics, quality formation personality, organization of activity); variety of spheres of activity on formation of value orientations of the person (activity of student government; group, course and "main" for faculty and higher education institution collective and creative affairs; extracurricular activity on subjects; activity of creative associations, etc.); changes in activities (socio-political, educational, labor, cultural and leisure, sports, communication).

\section{SUMMARY}

The article is devoted to peculiarities of formation of value orientations of modern student youth. The socio-economic preconditions of formation of value orientations of youth are revealed: conditionality of character and the direction of socialization of youth by transformation of a society; increasing the role of the subjects of the educational process in preparing young people to achieve life and professional success in the new environment; increasing social anxiety during the transformation of society, etc. It is proved that the formation of value orientations of students in the educational process of higher education institution is an effective means of socialization of student youth and is considered by us as a step-by-step process, which is a set of consistent, appropriate interactions of tutors and students (first stage), the development of their stability in the process of education of personal values (second stage) and effectiveness in educational and upbringing activities (third stage). The value orientations of modern students are revealed: life and professional values are a priority for student youth, material, spiritual, moral ones are less significant.

The article reveals socio-economic factors of formation of life and professional value orientations of student youth: the nature and directions of socialization of youth transform the social system; the role of the educational process in preparing young people to achieve life and professional success in the new environment; the social danger of degradation of value orientations of 
youth in the course of transformation of a society amplifies; the need for correction of value orientations in student youth on the basis of personalityoriented and differentiated approaches is growing. Theoretical bases of life and professional value orientations (content, components, signs and typology) are developed. The study identifies the system and types of life and professional value orientations of student youth. The authors constructed a pedagogical model of forming life and professional values of students, which provides for the unity of two types of socialization - through the creation of difficulties and through the creation of values, including ideas about higher education, which creates conditions for forming an individual capable of responding to new demands. which has the features of a creative personality aimed at transforming society. The technique of diagnostics of vital and professional value orientations of student's youth (the organization, principles, methods and equipment of research) is developed; the program of formation of life and professional value orientations of students, which determines their life and professional career; scientific and practical recommendations for the formation of life and professional values of students.

\section{REFERENCES}

1. Артьомова T. Європейські цінності: інтелектуальний простір цивілізаційного діалогу. Економічна теорія. 2018. № 3. С. 5-28.

2. Балагура О. Глобалізація морально-духовних цінностей в освітньому просторі. Вища школа. 2013. № 8. С. 89-94.

3. Боднар О.О. Співвідношення типів цінностей особистості і соціальної мужності як цінності. Становлення цінностей у психологічному вимірі соціального буття особистості. Соціальна мужність як изінність: матеріали Міжнародної науково-практичної конференції, 3-4 червня 2010 р., Львів-Кам'янець-Подільський / МОН України, Львівський національний ун-т ім. І. Франка; Кам'янецьПодільський національний ун-т ім. І. Огієнка та ін.; [редкол.: С.Д. Максименко, В.Й. Бочелюк, В.О. Васютинський та ін.]. Кам’янець-Подільський : Аксіома, 2010. С. 40-42.

4. Буруковська Н. Міф як засіб формування нових ціннісних орієнтацій в сфері сучасних наукових досліджень. Гуманітарнонаукове знання: розмаїття парадигми: матеріали міжнародної наукової конференції, 14-15 жовтня 2013 р., м. Чернівці / МОН України, Чернівецький національний ун-т ім. Ю. Федьковича; [редкол.: М.Г. Марчук, О.В. Рупташ, С.І. Мудра та ін.]. Чернівці : Чернівецький національний ун-т, 2013. С. 183-184.

5. Волошина С.В. Розвиток національних і загальнолюдських цінностей - домінувальний фактор самореалізації особистості: (модель освітнього соціалізувального простору). Виховна робота в школі. 2015. № 11. C. 6-8. 
6. Гавриленко М.О. Соціальні цінності та активність студента як провідні критерії та показники соціального виховання молоді. Сойіальна педагогіка: теорія та практика. 2012. № 1. С. 43-48.

7. Горлинський В.В. Інституційний вимір безпечного і сталого розвитку в умовах мережного суспільства. Практична філософія. 2012. № 4. C. 107-112.

8. Ісакова О.І. Аксіологія здоров'я молоді у сучасній філософській антропології. Загальна теорія здоров'я $i$ здоров'язбереження: колективна монографія / МОН України, Харківський національний педагогічний ун-т ім. Г.С. Сковороди; за заг. ред. Ю.Д. Бойчука. Харків : Рожко С.Г., 2017. С. 40-45.

9. Калошин В.Ф. Загальнолюдські цінності в освіті. Управління школою. 2019. № 4/6. С. 41-49.

10. Кишакевич Ю.Л. Іерархія цінностей у вихованні студентської молоді. Нові технології навчання: Наук.-метод. зб.: Вип. 31. Київ : Наук.-метод. центр вищ. освіти, 2018. С. 81-86.

11. Кобильник Л.Б. Особливості ціннісних орієнтацій студентів різного фаху. Методології та технології практичної психологї в системі вищої освіти: друга Міжнародна науково-практична конференція: тези доповідей / МОН України, НПУ ім. М.П. Драгоманова, Ін-т соціології, психології та управління, Каф. практичної психології та психотерапії; [редкол.: В.Б. Свтух, Н.І. Пов'якель, І.С. Булах та ін.]. Київ : НПУ ім. М.П. Драгоманова, 2009. С. 86-88.

12. Кострюков С. Загальнолюдські та національні культурні цінності: проблема єдності. Вища освіта Украӥни. 2008. № 3. С. 75-83.

13. Кофанова Е. Гражданские ценности как фактор образования: о задачах гражданского образования. Новые знания. 2006. № 2. С. 11-13.

14. Кузнєцов М.А. Структура почуття цінності власного життя у студентів. Особистість у кризових умовах та критичних ситуаціях життя: матеріали V Міжнародної науково-практичної конференції 28 лютого - 1 березня 2019 р. / МОН України, Сумський державний педагогічний ун-т ім. А.С. Макаренка; Ін-т психології ім. Г.С. Костюка НАПН України та ін.; [редкол.: С.Б. Кузікова, Р. Абрамцьов, А.В. Вертель та ін.]. Суми : Вид-во СумДПУ ім. А. С. Макаренка, 2019. C. $191-195$.

15. Лазарєв М.О. Самореалізація творчих i духовних цінностей особистості в евристичній освіті. Педагогічні науки: теорія, історія, інноваиійні технологіï: науковий журнал / МОН України, Сумський держ. пед. ун-т ім. А.С. Макаренка; [ред. кол.: А.А. Сбруєва, О.С. Антонова, Дж. Бішоп та ін.]. Суми : СумДПУ ім. А. С. Макаренка, 2014. № 7 (41). C. 270-280.

16. Мельник А.А. Смисложиттєві та ціннісні орієнтації студентської молоді. Методологї̈ та технології практичної психології в системі вищої освіти: друга Міжнародна науково-практична конференція: тези 
доповідей / МОН України, НПУ ім. М. П. Драгоманова, Ін-т соціології, психології та управління, Каф. практичної психології та психотерапії; [редкол.: В.Б. Свтух, Н.І. Пов'якель, І.С. Булах та ін.]. Київ : НПУ ім. М.П. Драгоманова, 2009. С. 114-116.

17. Олексин І.Я. Аксіологічний вимір життєвого світу особистості. Практична філософія. 2017. № 2. С. 38-44.

18. Попович М.В. Аксіологічні уявлення в груповій свідомості студентів вищих духовних навчальних закладів. Практична філософія. 2016. № 2. C. 23-28.

19. Савотина Н.А. Гражданские ценности в контексте проблем социализации студенческой молодёжи. Педагогика. 2010. № 7. С. 37-45.

20. Семків I. Крос-культурний аспект дослідження цінностей. Методології та технологї практичної психології в системі вищої освіти: друга Міжнародна науково-практична конференція: тези доповідей / МОН України, НПУ ім. М.П. Драгоманова, Ін-т соціології, психології та управління, Каф. практичної психології та психотерапії; [редкол.: В.Б. Свтух, Н.І. Пов'якель, І.С. Булах та ін.]. Київ : НПУ ім. М.П. Драгоманова, 2009. С. 174-176.

21. Терещенко Ю.І. Педагогіка: філософія затвердження людського в людині. Практична філософія. 2009. № 4. С. 110-119.

22. Шпот О.В. Дослідження впливу релігійності на розвиток духовних цінностей сучасної молоді : дипл. робота. Суми : СумДПУ ім. А.С. Макаренка, 2015. 73 с.

\section{Information about the authors:} Dieniezhnikov S. S.,

$\mathrm{Ph}$. D. in Philosophical Sciences,

Head of International Relations Department, Associate Professor at the Department of Management of Education and Pedagogy of Higher School

Educational Scientific Institute of Pedagogy and Psychology of the Sumy State Pedagogical University named after A. S. Makarenko 87, Romenska str., Sumy, 40002, Ukraine

Pshenychna L. V., Ph. D. in Sciences of State Management, Vice-Rector,

Professor at the Department of Management of Education and Pedagogy of Higher School

Educational Scientific Institute of Pedagogy and Psychology of the Sumy State Pedagogical University named after A. S. Makarenko 87, Romenska str., Sumy, 40002, Ukraine 